\title{
Streptomyces caeruleatus sp. nov., with dark blue diffusible pigment
}

\author{
Hong-hui Zhu, ${ }^{1}$ Jun Guo, ${ }^{1}$ Qing Yao, ${ }^{2}$ Song-zhen Yang, ${ }^{1}$ Ming-rong Deng ${ }^{1}$ \\ and Tai-hui $\mathrm{Li}^{1}$ \\ ${ }^{1}$ Guangdong Provincial Microbial Culture Collection and Application Key Laboratory, Guangdong \\ Insititute of Microbiology, Guangzhou, Guangdong 510070, PR China \\ ${ }^{2}$ South China Agricultural University, Guangzhou, Guangdong 510642, PR China
}

Correspondence

Hong-hui Zhu

zhuhonghui66@yahoo.com.cn
Actinomycetes are widespread Gram-positive bacteria with filamentous growth and high DNA $G+C$ contents (60-78 mol\%). Among the actinobacteria, members of the genus Streptomyces produce useful compounds, notably antibiotics, enzymes, enzyme inhibitors and pharmacologically active agents (Bérdy, 2005). The genus Streptomyces was first described by Waksman \& Henrici (1943) and now consists of more than 540 species with validly published names (Euzéby, 2008). The systematics of the genus Streptomyces at the species level, however, is still in a state of confusion and the genus is believed to be overspeciated (Groth et al., 1999). Strain GIMN4.002 ${ }^{\mathrm{T}}$ was isolated from tomato rhizosphere soil at Guangzhou, China, in April 2007. The soil sample was inoculated onto Gause's synthetic agar medium (Atlas, 1993) and incubated for 3-5 days at $28{ }^{\circ} \mathrm{C}$; the strain produced large quantities of dark blue diffusible pigment on this medium.

International Streptomyces Project (ISP) media were prepared according to the methods of Shirling \& Gottlieb

Abbreviations: DAP, diaminopimelic acid; ISP, International Streptomyces Project.

The GenBank/EMBL/DDBJ accession number for the $16 \mathrm{~S}$ rRNA gene sequence of strain GIMN4.002 ${ }^{\top}$ is G0329712.
(1966). Morphological and physiological characteristics were determined as recommended by Williams et al. (1989). Morphological observations of spores and mycelia were conducted by using light microscopy (Leica DM RAR) and scanning electron microscopy (Phillip FEIXL30). Physiological tests were carried out at $28{ }^{\circ} \mathrm{C}$ unless otherwise indicated. Melibiose, D-glucose, sucrose, D-fructose, D-xylose, L-rhamnose, L-arabinose, inositol and D-mannitol were tested as sole carbon source at concentrations of $0.1 \%(\mathrm{w} / \mathrm{v})$ and were filter-sterilized. Colour determinations were referenced against the Methuen Handbook of Colour (Kornerup \& Wanscher, 1978).

Analysis of the isomer of diaminopimelic acid (DAP) and whole-cell sugar composition followed the procedure described by Hasegawa et al. (1983) except that dried cells were used instead of colonies from agar plates. Fatty acid methyl esters were prepared by the trimethylsulphonium hydroxide method (Butte, 1983) and analysed by GC (6890; Hewlett Packard) using the Microbial Identification software package (Sasser, 1990). Menaquinones were extracted according to the method of Collins et al. (1977) and analysed by HPLC (Kroppenstedt, 1985). The base composition of genomic DNA of strain GIMN $4.002^{\mathrm{T}}$ was determined in $0.1 \times$ SSC by the method of Mandel \& Marmur (1968). Genomic DNA was extracted (Cui et al., 
2001) and the 16S rRNA gene amplified by PCR using universal bacterial $16 \mathrm{~S}$ rRNA gene primers. Forward primer F27 (5'-AGAGTTTGATCCTGGCTCAG-3') and reverse primer 1522R ( $5^{\prime}$-AAGGAGGTGATCCAGCCGCA-3') were adapted from primers $\mathrm{pA}$ and $\mathrm{pH}$ of Edwards et al. (1989). The 16S rRNA gene was sequenced with an automated capillary DNA sequencing system (ABI 3730) and a BigDye terminator cycle sequencing kit (Applied Biosystems).

DNA-DNA relatedness was determined by the fluorometric microdilution plate method (Ezaki et al., 1988; Sawabe et al., 1998). Levels of relatedness were expressed as percentage values. The fluorescence intensity was measured with a MicroFluor reader (Dynatech) at wavelengths of $360 \mathrm{~nm}$ for excitation and $450 \mathrm{~nm}$ for emission. Fluorescence intensity of a well of salmon sperm DNA was calculated as 0 , and the intensity of the well which emitted the strongest fluorescence was calculated as $100 \%$.

Chemotaxonomic analyses showed that the cell wall contained LL-DAP, typical of cell wall type I (Lechevalier \& Lechevalier, 1970). Whole-cell hydrolysates contained predominantly glucose and hence no diagnostic whole-cell sugars. The predominant menaquinones were MK-9 $\left(\mathrm{H}_{8}\right)$ $(45.53 \%)$, MK-9 $\left(\mathrm{H}_{2}\right)(8.25 \%)$, MK-9 $\left(\mathrm{H}_{4}\right)(5.78 \%)$ and MK-9 $\left(\mathrm{H}_{6}\right) \quad(4.52 \%)$, and MK-10 $\left(\mathrm{H}_{2}\right)(29.11 \%)$. Strain GIMN4.002 ${ }^{\mathrm{T}}$ contained straight-chain, iso- and anteisobranched fatty acids and a proportion of unsaturated fatty acids. The major cellular fatty acids were $\mathrm{C}_{16: 0}(25.19 \%)$, iso- $\mathrm{C}_{16: 0}(18.67 \%)$, anteiso- $\mathrm{C}_{15: 0}(10.46 \%)$, cis9- $\mathrm{C}_{16: 1}$ $(7.51 \%)$, iso- $\mathrm{C}_{14: 0}(7.31 \%)$, cyclo- $\mathrm{C}_{17: 0}(4.80 \%), \mathrm{C}_{14: 0}$ $(4.37 \%)$, iso- $\mathrm{C}_{15: 0}(3.90 \%), \mathrm{C}_{15: 0}(3.67 \%)$, anteiso- $\mathrm{C}_{17: 0}$ $(2.56 \%)$ and iso- $\mathrm{C}_{16: 1} \mathrm{H}(1.08 \%)$. The $\mathrm{G}+\mathrm{C}$ content of the genomic DNA was $70.7 \mathrm{~mol} \%$.

A 1397 bp 16S rRNA gene sequence was determined for strain GIMN4.002 ${ }^{\mathrm{T}}$. A BLAST search (Altschul et al., 1997) of the GenBank database using this sequence showed its similarity to many species of the genus Streptomyces and, in particular, it was $99.4 \%$ similar to Streptomyces lincolnensis B91 (DQ462654.1), 99.2\% similar to 'Streptomyces viridochromogenes subsp. komabensis' NBRC 13859 and 98-99\% similar to the other species in the genus Streptomyces.

A phylogenetic tree based on 16S rRNA gene sequences representing members of the genus Streptomyces was reconstructed using the neighbour-joining method of Saitou \& Nei (1987) with CLUSTAL W (version 1.81) (Jeanmougin et al., 1998; Thompson et al., 1997) and MEGA (version 3.1, Kumar et al., 2001) (Fig. 1). For the neighbour-joining analysis, a distance matrix was calculated according to Kimura's two-parameter correction model (Kimura, 1980). The minimum-evolution and maximum-parsimony methods were also used for tree reconstruction (Kumar et al., 2004). Branches marked with an asterisk are conserved in all methods used. This tree shows the close phylogenetic association of strain GIMN $4.002^{\mathrm{T}}$ with certain members of other species in the genus Streptomyces.

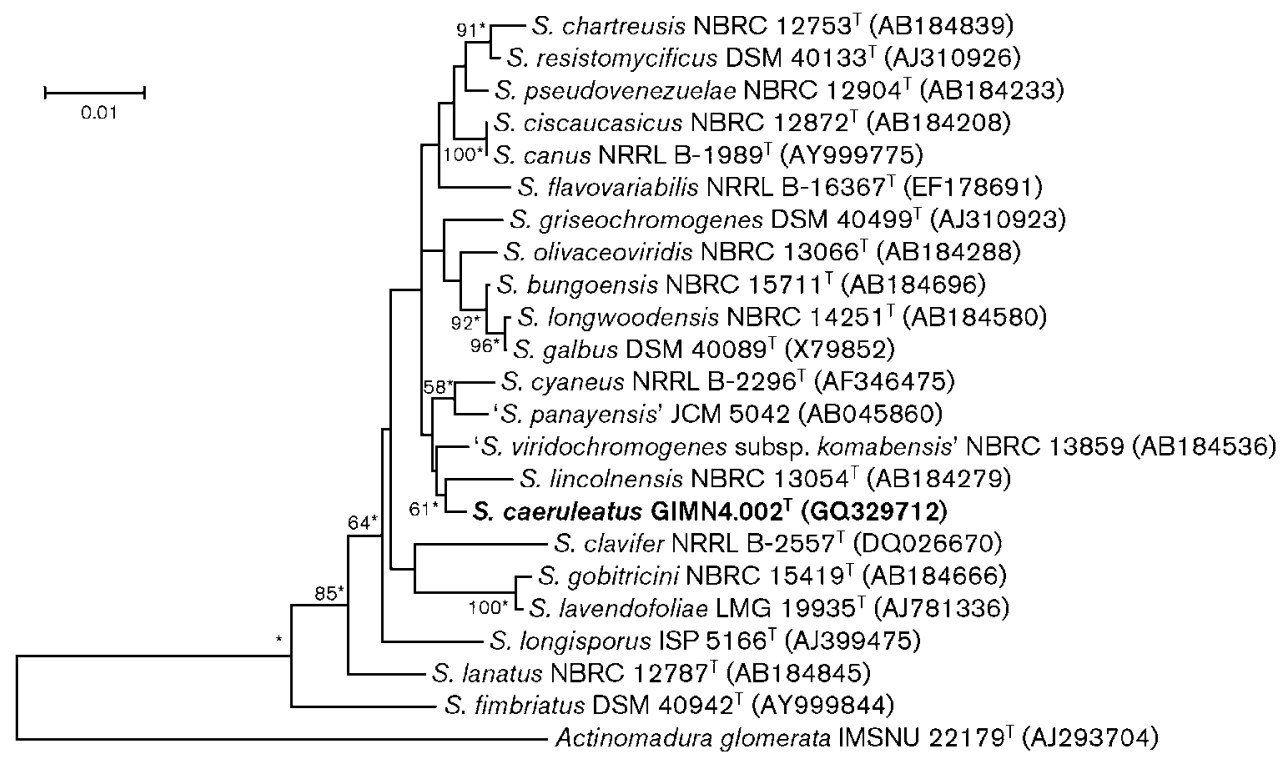

Fig. 1. Unrooted neighbour-joining tree reconstructed from 16S rRNA gene sequences, showing the phylogenetic relationship between strain GIMN4.002 ${ }^{\top}$ and species of the genus Streptomyces belonging to the major, minor and single-member clusters defined by Williams et al. (1983). Actinomadura glomerata IMSNU $22179^{\top}$ was used as the outgroup. Bootstrap values (expressed as percentages of 1000 replications) greater than $50 \%$ are given at nodes. Minimum-evolution and maximumparsimony methods were also used for tree reconstruction. Branches marked with an asterisk are conserved in all methods used. Bar, 0.01 substitutions per nucleotide position. 

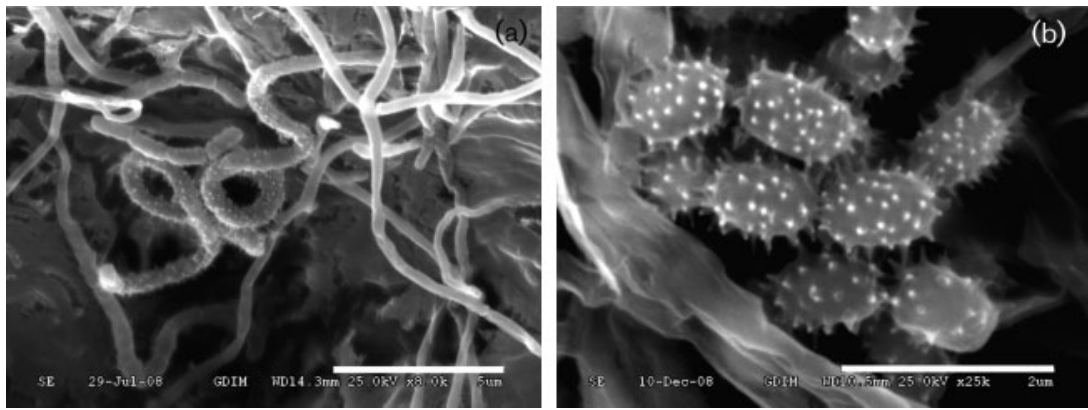

Fig. 2. Scanning electron micrographs of strain GIMN4.002 ${ }^{\top}$ grown on inorganic salts/ starch agar (ISP 4 ) at $28{ }^{\circ} \mathrm{C}$ for 14 days. Note looped spore chains of spiny spores. Bars, $5 \mu \mathrm{m}$ (a) and $2 \mu \mathrm{m}$ (b).

The morphological and physiological characteristics of strain GIMN4.002 ${ }^{\mathrm{T}}$, including cell-wall type, wholecell sugar pattern and fatty acid profile, were consistent with the characteristics of members of the genus Streptomyces.

Morphological features were observed on yeast extract/ malt extract agar (ISP 2), oatmeal agar (ISP 3), inorganic salts/starch agar (ISP 4) and glycerol-asparagine agar (ISP 5). Cultures were incubated for 2 weeks at $28{ }^{\circ} \mathrm{C}$. Strain GIMN4.002 $2^{\mathrm{T}}$ had characteristics typical of the genus Streptomyces and microscopic observations revealed a branched mycelium without verticils. The aerial mycelium produced spiral chains of cylindrical and spiny-surfaced spores (Fig. 2). Strain GIMN4.002 ${ }^{\mathrm{T}}$ developed well on ISP 2, ISP 3, ISP 5, Czapek's agar (Atlas, 1993) and Gause's synthetic agar. It exhibited moderate growth on ISP 4. Diffusible pigments of different colours were produced on the various different media (Table 1), ranging from dark blue (20-E-5) to blackish-blue (20-F-8). Melanin was produced on tyrosine agar ISP 7.

Strain GIMN4.002 ${ }^{\mathrm{T}}$ produces a greyish-white aerial mycelium and a blue substrate mycelium on ISP 2, and looped spore chains without verticils and with spiny spores. Melanin is produced. Dark blue or blue diffusible pigments are produced. Pigment production was $\mathrm{pH}$ sensitive. Comparison of the cultural characteristics of strain GIMN4.002 ${ }^{\mathrm{T}}$ and its closest phylogenetic neighbours (Table 2) revealed significant differences.
Streptomyces lincolnensis differs from strain GIMN4.002 ${ }^{\mathrm{T}}$ in that it produces long and flexuous spore chains with ovalshaped and smooth spores while Streptomyces viridochromogenes differs from strain GIMN4.002 ${ }^{\mathrm{T}}$ in that melanin is not produced on ISP 7 media and milk coagulation was negative. Despite the high 16S rRNA gene sequence similarity between GIMN4.002 ${ }^{\mathrm{T}}$ and Streptomyces lincolnensis, morphological and cultural characterics and carbon-utilization patterns are different (Table 2), indicating that GIMN4.002 ${ }^{\mathrm{T}}$ is not a strain of Streptomyces lincolnensis. DNA-DNA relatedness between strain GIMN4.002 ${ }^{\mathrm{T}}$ and Streptomyces lincolnensis NBRC $13054^{\mathrm{T}}$ was found to be $32.17 \%$, far below the $70 \%$ threshold value proposed by Wayne et al. (1987) for indicating species status. Thus, DNA-DNA hybridization studies confirmed that strain GIMN4.002 ${ }^{\mathrm{T}}$ is unique and support the classification of strain GIMN4.002 ${ }^{\mathrm{T}}$ as a novel species of the genus Streptomyces, for which the name Streptomyces caeruleatus sp. nov. is proposed.

\section{Description of Streptomyces caeruleatus sp. nov.}

Streptomyces caeruleatus (ca.e.ru.le.a'tus. L. masc. adj. caeruleatus dark blue coloured, referring to the dark blue pigments produced).

Aerobic, Gram-positive, catalase-positive actinomycete that forms a greyish-white aerial mycelium and a blue substrate mycelium on ISP 2 . The substrate mycelium does not fragment. Looped chains of spiny-surfaced spores are

Table 1. Cultural characteristics of strain GIMN4.002

ISP media (Shirling \& Gottlieb, 1966) are described in the text. Diffusible pigment was observed on most of the media listed. Colour comparisons were taken from Kornerup \& Wanscher (1978).

\begin{tabular}{|c|c|c|c|c|c|c|}
\hline Characteristic & ISP 2 & ISP 3 & ISP 4 & ISP 5 & Czapek's agar & $\begin{array}{l}\text { Gause's synthetic } \\
\text { agar }\end{array}$ \\
\hline Growth & Good & Good & Moderate & Good & Luxuriant & Good \\
\hline \multicolumn{7}{|l|}{ Colour of: } \\
\hline Aerial mycelium & Greyish-white & Greyish-white & Bright yellow & Greyish-white & Bright blue & White \\
\hline Substrate mycelium & Blue & Reddish-brown & Reddish-brown & Blue & Blue & Reddish-brown \\
\hline
\end{tabular}


Table 2. Differential cultural characteristics of strain GIMN4.002 ${ }^{\top}$ and its phylogenetic neighbours

Strains: 1, strain GIMN4.002 ${ }^{\mathrm{T}} ; 2$, Streptomyces lincolnensis NBRC $13054^{\mathrm{T}}$; 3, Streptomyces viridochromogenes ISP $5110^{\mathrm{T}}$. Data for reference strains were taken from Shirling \& Gottlieb $(1968,1969)$, Gause et al. (1983) and Williams et al. (1983). +, Positive; -, negative; w, weakly positive reaction; ND, no data available.

\begin{tabular}{|lccc|}
\hline Characteristics & $\mathbf{1}$ & $\mathbf{2}$ & $\mathbf{3}$ \\
\hline Colony colour on ISP 2 & $\begin{array}{c}\text { Greyish-white } \\
\text { Spore shape }\end{array}$ & $\begin{array}{c}\text { Bright-yellow } \\
\text { Oval, smooth }\end{array}$ & $\begin{array}{c}\text { Green } \\
\text { Spiny }\end{array}$ \\
Spore chain morphology & Looped & Long, flexuous & Spiral \\
Production of diffusible & Dark blue & Yellow & Green \\
pigment & & & \\
Milk coagulation & + & w & - \\
Melanin production & + & + & - \\
Utilization of: & & & \\
$\quad$ Melibiose & + & ND & + \\
Sucrose & - & + & - \\
D-Fructose & + & + & - \\
\hline
\end{tabular}

produced. Diffusible pigments are produced on ISP 2, ISP 5, Czapek's agar and Gause's synthetic agar, but not in ISP 3 or ISP 4. Melanin pigment is produced on ISP 7. Although growth on ISP 4 is initially slow, very good growth with profuse sporulation is observed on this medium after 14 days. Develops well on ISP 2, ISP 3, ISP 5, Czapek's agar and Gause's synthetic agar. Moderate growth on ISP 4. Substrate mycelium is reddish-brown on ISP 3, ISP 4 and Gause's synthetic agar, but blue on ISP 2, ISP 5 and Czapek's agar. The cell wall contains LL-DAP (cell wall type I). The whole cell sugar pattern contains glucose. The predominant menaquinones are $\mathrm{MK}-9\left(\mathrm{H}_{8}\right)$, MK-9 $\left(\mathrm{H}_{2}\right)$, MK-9 $\left(\mathrm{H}_{4}\right)$ and MK-9 $\left(\mathrm{H}_{6}\right)$, and $\mathrm{MK}-10\left(\mathrm{H}_{2}\right)$. The major cellular fatty acids are $\mathrm{C}_{16: 0}$, iso- $\mathrm{C}_{16: 0}$, anteiso$\mathrm{C}_{15: 0}$, cis9- $\mathrm{C}_{16: 1}$, iso- $\mathrm{C}_{14: 0}$, cyclo- $\mathrm{C}_{17: 0}, \mathrm{C}_{14: 0}$, iso- $\mathrm{C}_{15: 0}$, $\mathrm{C}_{15: 0}$, anteiso- $\mathrm{C}_{17: 0}$ and iso- $\mathrm{C}_{16: 1} \mathrm{H}$. Antibacterial activity against Bacillus subtilis, Micrococcus luteus and Staphylococcus aureus, but not against Escherichia coli, Pseudomonas aeruginosa or Salmonella choleraesuis. Grows with melibiose, D-glucose, D-fructose, D-xylose, L-rhamnose, $\mathrm{L}$-arabinose, inositol and D-mannitol as sole carbon source. $\mathrm{H}_{2} \mathrm{~S}$ production is positive.

The type strain is GIMN4.002 ${ }^{\mathrm{T}}$ (=CCTCC M 208213 ${ }^{\mathrm{T}}$ $\left.=\mathrm{NRRL} B-24802^{\mathrm{T}}\right)$. The DNA $\mathrm{G}+\mathrm{C}$ content of the type strain is $70.7 \mathrm{~mol} \%$.

\section{Acknowledgements}

This research was supported by the National Nature Science Foundation of China (project no. 30770067), International S\&T Cooperation Program of China (project no. 2008DFA31560), Guangdong Ministry of Science and Technology, PR China (project nos 2009B050300003 and 2008B021400005), Guangdong Academy of Sciences, PR China (project no: cx200702). We thank Dr David P. Labeda (National Center for Agricultural Utilization Research) for his constructive suggestions and grammatical correction of the manuscript.

\section{References}

Altschul, S. F., Madden, T. L., Schäffer, A. A., Zhang, J., Zhang, Z., Miller, W. \& Lipman, D. J. (1997). Gapped BLAST and PSI-BLAST: a new generation of protein database search programs. Nucleic Acids Res 25, 3389-3402.

Atlas, R. M. (1993). Handbook of Microbiological Media. Edited by L. C. Parks. Boca Raton, FL: CRC Press.

Bérdy, J. (2005). Bioactive microbial metabolites. J Antibiot (Tokyo) 58, $1-26$.

Butte, W. (1983). Rapid method for the determination of fatty acid profiles from fats and oils using trimethylsulphonium hydroxide for transesterification. J Chromatogr A 261, 142-145.

Collins, M. D., Pirouz, T., Goodfellow, M. \& Minnikin, D. E. (1977). Distribution of menaquinones in actinomycetes and corynebacteria. $J$ Gen Microbiol 100, 221-230.

Cui, X.-L., Mao, P.-H., Zeng, M., Li, W.-J., Zhang, L.-P., Xu, L.-H. \& Jiang, C.-L. (2001). Streptimonospora salina gen. nov., sp. nov., a new member of the family Nocardiopsaceae. Int J Syst Evol Microbiol 51, 357-363.

Edwards, U., Rogall, T., Blöcker, H., Emde, M. \& Böttger, E. C. (1989). Isolation and direct complete nucleotide determination of entire genes. Characterization of gene coding for $16 \mathrm{~S}$ ribosomal RNA. Nucleic Acids Res 17, 7843-7853.

Euzéby, J. P. (2008). List of prokaryotic names with standing in nomenclature. http://www.bacterio.cict.fr

Ezaki, T., Hashimoto, Y., Takeuchi, N., Yamamoto, H., Liu, S.-L., Miura, H., Matsui, K. \& Yabuuchi, E. (1988). Simple genetic method to identify viridans group streptococci by colorimetric dot hybridization and fluorometric hybridization in microdilution wells. $J$ Clin Microbiol 26, 1708-1713.

Gause, G. F., Preobrazhenskaya, T. P., Sveshnikova, M. A., Terekhova, L. P. \& Maximova, T. S. (1983). A Guide for the Determination of Actinomycetes. Genera Streptomyces, Streptoverticillium, and Chainia. Moscow: Nauka (in Russian).

Groth, I., Vettermann, R., Shuetze, B., Schumann, P. \& SaizJimenez, C. (1999). Actinomycetes in Karstic caves of northern Spain (Altamira and Tito Bustillo). J Microbiol Methods 36, 115122.

Hasegawa, T., Takizawa, M. \& Tanida, S. (1983). A rapid analysis for chemical grouping of aerobic actinomycetes. J Gen Appl Microbiol 29, 319-322.

Jeanmougin, F., Thompson, J. D., Gouy, M., Higgins, D. G. \& Gibson, T. J. (1998). Multiple sequence alignment with Clustal X. Trends Biochem Sci 23, 403-405.

Kimura, M. (1980). A simple method for estimating evolutionary rates of base substitutions through comparative studies of nucleotide sequences. J Mol Evol 16, 111-120.

Kornerup, A. \& Wanscher, J. H. (1978). Methuen Handbook of Colour, 3rd edn. London: Eyre Methuen.

Kroppenstedt, R. M. (1985). Fatty acid and menaquinone analysis of actinomycetes and related organisms. In Chemical Methods in Bacterial Systematics (Society of Applied Bacteriology Technical Series vol. 20), pp. 173-199. Edited by M. Goodfellow \& D. E. Minnikin. New York: Academic Press.

Kumar, S., Tamura, K., Jakobsen, I. B. \& Nei, M. (2001). MEGA2: molecular evolutionary genetics analysis software. Bioinformatics 17, 1244-1245.

Kumar, S., Tamura, K. \& Nei, M. (2004). MEGA3: integrated software for molecular evolutionary genetics analysis and sequence alignment. Brief Bioinform 5, 150-163. 
Lechevalier, H. A. \& Lechevalier, M. P. (1970). A critical evaluation of the genera of aerobic actinomycetes. In The Actinomycetales, pp. 393405. Edited by H. Prauser. Jena: VEB Gustav Fischer.

Mandel, M. \& Marmur, J. (1968). Use of ultraviolet absorbancetemperature profile for determining the guanine plus cytosine content of DNA. Methods Enzymol 12B, 195-206.

Saitou, N. \& Nei, M. (1987). The neighbor-joining method: a new method for reconstructing phylogenetic trees. Mol Biol Evol 4, 406425.

Sasser, M. (1990). Identification of bacteria by gas chromatography of cellular fatty acids, MIDI Technical Note 101. Newark, DE: MIDI Inc.

Sawabe, T., Makino, H., Tatsumi, M., Nakano, K., Tajima, K., Iqbal, M. M., Yumoto, I., Ezura, Y. \& Christen, R. (1998). Pseudoalteromonas bacteriolytica sp. nov., a marine bacterium that is the causative agent of red spot disease of Laminaria japonica. Int J Syst Bacteriol 48, 769774.

Shirling, E. B. \& Gottlieb, D. (1966). Methods for characterization of Streptomyces species. Int J Syst Bacteriol 16, 313-340.

Shirling, E. B. \& Gottlieb, D. (1968). Cooperative description of type cultures of Streptomyces III. Additional species descriptions from first and second studies. Int J Syst Bacteriol 18, 279-392.
Shirling, E. B. \& Gottlieb, D. (1969). Cooperative description of type cultures of Streptomyces. IV. Species descriptions from the second, third and fourth studies. Int J Syst Bacteriol 19, 391-512.

Thompson, J. D., Gibson, T. J., Plewniak, F., Jeanmougin, F. \& Higgins, D. G. (1997). The CLUSTAL_X windows interface: flexible strategies for multiple sequence alignment aided by quality analysis tools. Nucleic Acids Res 25, 4876-4882.

Waksman, S. A. \& Henrici, A. T. (1943). The nomenclature and classification of the actinomycetes. J Bacteriol 46, 337-341.

Wayne, L. G., Brenner, D. J., Colwell, R. R., Grimont, P. A. D., Kandler, O., Krichevsky, M. I., Moore, L. H., Moore, W. E. C., Murray, R. G. E. \& other authors (1987). International Committee on Systematic Bacteriology. Report of the ad hoc committee on reconciliation of approaches to bacterial systematics. Int J Syst Bacteriol 37, 463-464.

Williams, S. T., Goodfellow, M., Alderson, G., Wellington, E. M. H., Sneath, P. H. A. \& Sackin, M. J. (1983). Numerical classification of Streptomyces and related genera. J Gen Microbiol 129, 1743-1813.

Williams, S. T., Goodfellow, M. \& Alderson, G. (1989). Genus Streptomyces Waksman and Henrici 1943, 339 ${ }^{\mathrm{AL}}$. In Bergey's Manual of Systematic Bacteriology, vol. 4, pp. 2452-2492. Edited by S. T. Williams, M. E. Sharpe \& J. G. Holt. Baltimore: Williams \& Wilkins. 